\title{
Heterhelus buzina sp.n. (Coleoptera: Kateretidae) from Rovno amber: the first proxy for Sambucus in the Eocene of Eastern Europe
}

\author{
J. Kupryjanowicz'1, G.Yu. Lyubarsky², E.E. Perkovsky ${ }^{3,4}$ \\ ${ }^{1}$ Andrzej Myrcha's University Centre of Natural Sciences, University of Biatystok, Bialystok, $15-$ \\ 089 Poland.E-mail: kuprzool@uwb.edu.pl \\ 2 Zoological Museum, Moscow State University, ul. Bol'shaya Nikitskaya 2, Moscow, 125009 \\ Russia.E-mail: lgeorgy@rambler.ru \\ ${ }^{3}$ I.I. Schmalhausen Institute of Zoology, National Academy of Sciences of Ukraine, ul. Bogdana \\ Khmel'nitskogo 15, Kiev, 0103001601 Ukraine.E-mail: perkovsk@gmail.com \\ ${ }^{4}$ A.A. Borissiak Paleontological Institute, Russian Academy of Sciences, Profsoyuznaya Str. 123, \\ Moscow, 117868 Russia.
}

ABSTRACT. Heterhelus buzina sp.n. is described from Rovno amber. The new species seems similar to the extant H. scutellaris (Heer, 1841), but differs from its by size (length $1.8 \mathrm{~mm}$ ), relatively small scape, longer elytra exposing two complete abdominal tergites, and confused elytral puncturation. All extant species of Heterhelus develop on Sambucus; the Heterhelus record from Rovno amber is the first indication of Sambucus presence in Eocene flora of Eastern Europe.

How to cite this article: Kupryjanowicz J., Lyubarsky G.Yu., Perkovsky E.E. 2021. Heterhelus buzina sp.n. (Coleoptera: Kateretidae) from Rovno amber: the first proxy for Sambucus in the Eocene of Eastern Europe // Invert. Zool. Vol.18. No.1. P.16-24. doi: 10.15298/invertzool.18.1.02

KEY WORDS: Oise amber, Heterhelus scutellaris, Priabonian, pollination.

\section{Heterhelus buzina sp.n. (Coleoptera: Kateretidae) из ровенского янтаря - первый связанный с бузиной вид из эоцена Восточной Европы}

\footnotetext{
Я. Куприянович ${ }^{1}$, Г.Ю. Любарский², Е.Э. Перковский ${ }^{3,4}$

${ }^{1}$ Andrzej Myrcha's University Centre of Natural Sciences, University of Biatystok, Biatystok, 15089 Poland.E-mail: kuprzool@uwb.edu.pl

2 Зоологический музей МГУ, ул. Большая Никитская 2, Москва 125009 Pоссия. E-mail: lgeorgy@rambler.ru

${ }^{3}$ Институт зоологии им. И. И. Шмальгаузена НАН Украины, ул. Б. Хмельницкого, 15, Киев, 01030, Украина. E-mail: perkovsk@gmail.com

${ }^{4}$ Палеонтологический институт им. А.А. Борисяка РАН, Профсоюзная ул. 123, Москва 117997, Россия.
}

РЕЗЮМЕ. Описан Heterhelus buzina sp.n. из ровенского янтаря. Новый вид похож на современный вид H. scutellaris (Heer, 1841), отличается от него меньшей длиной тела (1,8 мм), относительно маленьким скапусом, более длинными надкрыльями, которые оставляют свободными два абдоминальных тергита, смешанной пунктировкой 
надкрылий. Все современные виды Heterhelus развиваются на Sambucus; находка Heterhelus в ровенском янтаре - первое указание на присутствие Sambucus в эоценовой флоре Восточной Европы.

Как цитировать эту статью: Kupryjanowicz J., Lyubarsky G.Yu., Perkovsky E.E. 2021. Heterhelus buzina sp.n. (Coleoptera: Kateretidae) from Rovno amber: the first proxy for Sambucus in the Eocene of Eastern Europe // Invert. Zool. Vol.18. No.1. P.16-24. doi: 10.15298/invertzool.18.1.02

КЛЮЧЕВЫЕ СЛОВА: янтарь Уазы, Heterhelus scutellaris, приабон, опыление.

\section{Introduction}

Beetles from Rovno amber are understudied (Bukejs et al., 2020); only 60 species, 51 genera from 21 families have been reported so far (Bukejs et al., 2020; Bukejs, Legalov, 2020; Sokolov, Perkovsky, 2020; Legalov et al., 2021). In this paper we add to Rovno amber coleopterofauna a new species, genus and family.

Better studied Rovno hymenopterofauna includes 135 species, 66 of which are known from Baltic amber (Radchenko, Perkovsky, 2020; Simutnik et al., 2020); for Rovno coleopterofauna the share of Baltic species is only 13\% (Bellés, Perkovsky, 2016; Jałoszynski, Perkovsky, 2016, 2019; Nadein et al., 2016; Nazarenko, Perkovsky, 2016; Perkovsky, 2016; Tshernyshev, 2016; Bogri et al., 2018; Bukejs et al., 2018, 2020; Legalov et al., 2018, 2019; Petrov, Perkovsky, 2018; Bukejs, Legalov, 2019a, b, 2020; Kupryjanowicz et al., 2019; Kazantsev, Perkovsky, 2020; Kypke, Solodovnikov, 2020; Lyubarsky, Perkovsky, 2020; Sokolov, Perkovsky, 2020; this paper).

The species is related to the family Kateretidae: truncate elytra with three complete abdominal tergites exposed, antennae with 11 antennomeres, looser 3-segmented club, tarsal formula 5-5-5, tarsomere 4th the shortest, prothoracic and mesothoracic trochantin exposed, prosternal process short, open procoxal cavities, and all coxae widely separated. The modern fauna of the family are not well understood, and only partial revisions exist (Hisamatsu, 2011).

There are nine known fossil species of Kateretidae. The oldest is Lebanoretes andelmani Kirejtshuk et Azar, 2008, from Barremian Leb- anese amber (Kirejtshuk, Azar, 2008). Furcalabratum burmanicum Poinar et Brown, 2018, Cretaretes minimus Peris et Jelínek, 2020, Eoceniretes antiquus Peris et Jelínek, 2020 (Poinar, Brown, 2018; Peris, Jelínek, 2020), Electrumeretes birmanicus Peris et Jelínek, 2019 and Polliniretes penalveri Peris et Jelínek, 2019 (Peris, Jelínek, 2019) were described from Cenomanian Burmese (Kachin) amber. Two species were described from Ypresian Oise amber: Eoceniretes yantaricus Kirejtshuk et Nel, 2008 and Heterhelus expressus Kirejtshuk et Nel, 2008 (Kirejtshuk, Nel, 2008) and one species from the late Priabonian: Amartus petrefactus Wickham, 1912 (Florissant: Wickham, 1912).

Kateretid beetles are becoming essential for understanding the evolution of early pollination strategies, and also the rapid success of flowering plants during the mid-Cretaceous. Kateretidae showed mutualisms with a variety of gymnosperms and one angiosperm host during the Cretaceous (Peris et al., 2020), thus demonstrating how a gymnosperm-to-angiosperm shift occurred during the Cretaceous amongst the generalist pollen-feeding family of beetles, driving the subsequent success of flowering plants (Peris et al., 2020). The gymnosperm hosts (as pollen) were cycads, ginkgoaleans, and bennettitaleans, whereas the angiosperm host (also as pollen) was a water lily (Nymphaeales: Nymphaeaceae). It seems important to trace the evolution of this family in the further history of the development of pollination.

The new species belongs to the genus Heterhelus Jacquelin du Val, 1858. Diagnosis of this genus: body oval, convex dorsally; pronotum transverse, projecting at mid-length or uniformly rounded lateral margins; disc with punctures 
smaller than the eye facet; posterior angles obtusely angulate; basal margin nearly straight or with slight curvature; male abdominal tergite VIII externally visible; tarsal claws simple.

\section{Material and Methods}

The beetle inclusion is preserved in a polished piece of amber (Fig. 1A), yellowish in colour, without supplementary fixation. The amber piece is elongate. Digital photographs were taken in the Laboratory of Evolutionary Biology and Insect Ecology at the Institute of Biology, University of Białystok (Poland). Images were obtained with an Olympus DSX110 stereomicroscope and a camera with a colour CCD image sensor (1/1.8 inch, 2.01 megapixels), equipped with a DSXPLFL 3.6x lens. The specimen drawings were made using CorelDrawX6.

The holotype will be deposited at the Professor Andrzej Myrcha University Centre of Nature (UCP), University of Białystok (Białystok, Poland).

\section{Taxonomical part}

Family Kateretidae Erichson 1843

Genus Heterhelus Jacquelin du Val, 1858

Species type. Cercus sambuci Erichson 1843 [= Heterhelus scutellaris (Heer, 1841)], recent.

\section{Heterhelus (Heterhelus) buzina sp.n. Figs. 1, 2.}

HOLOTYPE. The specimen, in Rovno amber, deposited under accession number UCP No. 287. No syninclusions.

Type-locality: Klesov (Ukraine).

DIAGNOSIS. Length $1.8 \mathrm{~mm}$. Scape relatively small. Elytra exposing two complete abdominal tergites, elytral puncturation confused. Tarsal claws simple, without basal tooth.

DESCRIPTION. Body (Fig. 1: A, B) parallel-sided, convex, reddish-yellow, dully shining, covered with whitish setae. Head transverse and short, somewhat shorter than the distance between the eyes, densely punctate, punctures on disc smaller than the eye-facet, separated by 1-2 diameters (Fig. 1C). Antennal (Fig. 1E) insertions hidden behind projections of the frons; antennae 11-segmented with an indistinct 3segmented, loosely articulated club. Antennae 1.1 times longer than the greatest width of the head, including eyes, with club 3-segmented; approximate ratio of segments: $31: 10: 7: 6$ : $7: 5: 6: 5: 9: 9: 12$. Two apical segments are missing on the left antenna. Scape relatively small, elongated, not very long, 2.18 times longer than its width. Eyes prominent, ocular setae absent. Labrum moderately arcuate (Fig. 1C). Terminal segment of labial palpus elongateoval (Fig. 1D).

Pronotum (Figs. 1B) convex, transverse, 1.5 times as wide as long; anterior margin slightly convex, anterior corner not prominent; anterior margin unbordered; lateral margin bordered; sides not explanate, not ciliate; basal margin indistinctly bordered, almost straight; punctures on disc similar in size to those on the head; posterior angles slightly obtuse.

Length of prosternum (excluding prosternal process) 1.17 times as long as the length of the mesoventrite, length of mesoventrite 0.5 times as long as the length of the metaventrite; prosternal process slender, subparallel-sided, apex truncate (Fig. 1F). Procoxae transverse, separated. Metaventrite convex, shining, densely covered with whitish or yellowish setae; punctures on disc about the same size as those on the head, separated by one diameter in the middle, becoming denser laterally (Fig. 2A). Mesocoxae and metacoxae widely separated, metacoxae not reaching the elytra at the sides. Inter-mesocoxal distance separated by 2.4 times the width of the inter-procoxal distance. Inter-metacoxal distance separated by 3.6 times the width of the inter-procoxal distance.

Six visible abdominal segments; abdominal segment 1 is the longest. Abdominal sternites shining; approximate ratio of length of abdominal sternites I-VI is $36: 10: 10: 23: 22: 8$ (Fig. 2B); abdominal sternite VI short, the greatest width of the sixth abdominal sternite 5.5 

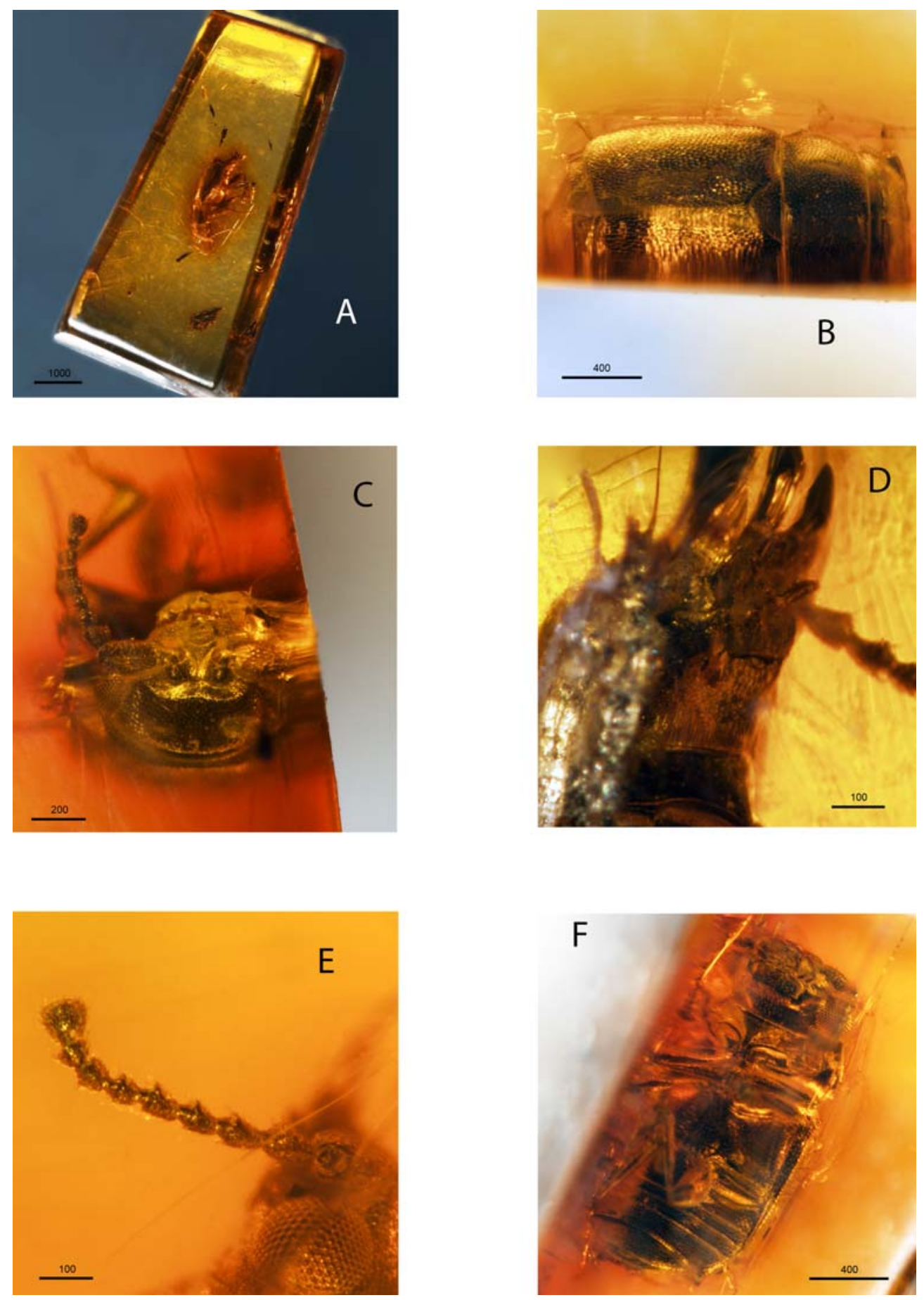

Fig. 1. Heterhelus buzina sp.n. (photo): A - total view, amber piece; B - total view, dorsal; C - head, in front; D - head, lateral; E - antenna; F - total view, ventral.

Рис. 1. Heterhelus buzina sp.n., фото: А - общий вид янтаря с включением; В 一 общий вид, дорзально; С — голова спереди; D — голова сбоку; Е — усик; F — общий вид, вентрально. 

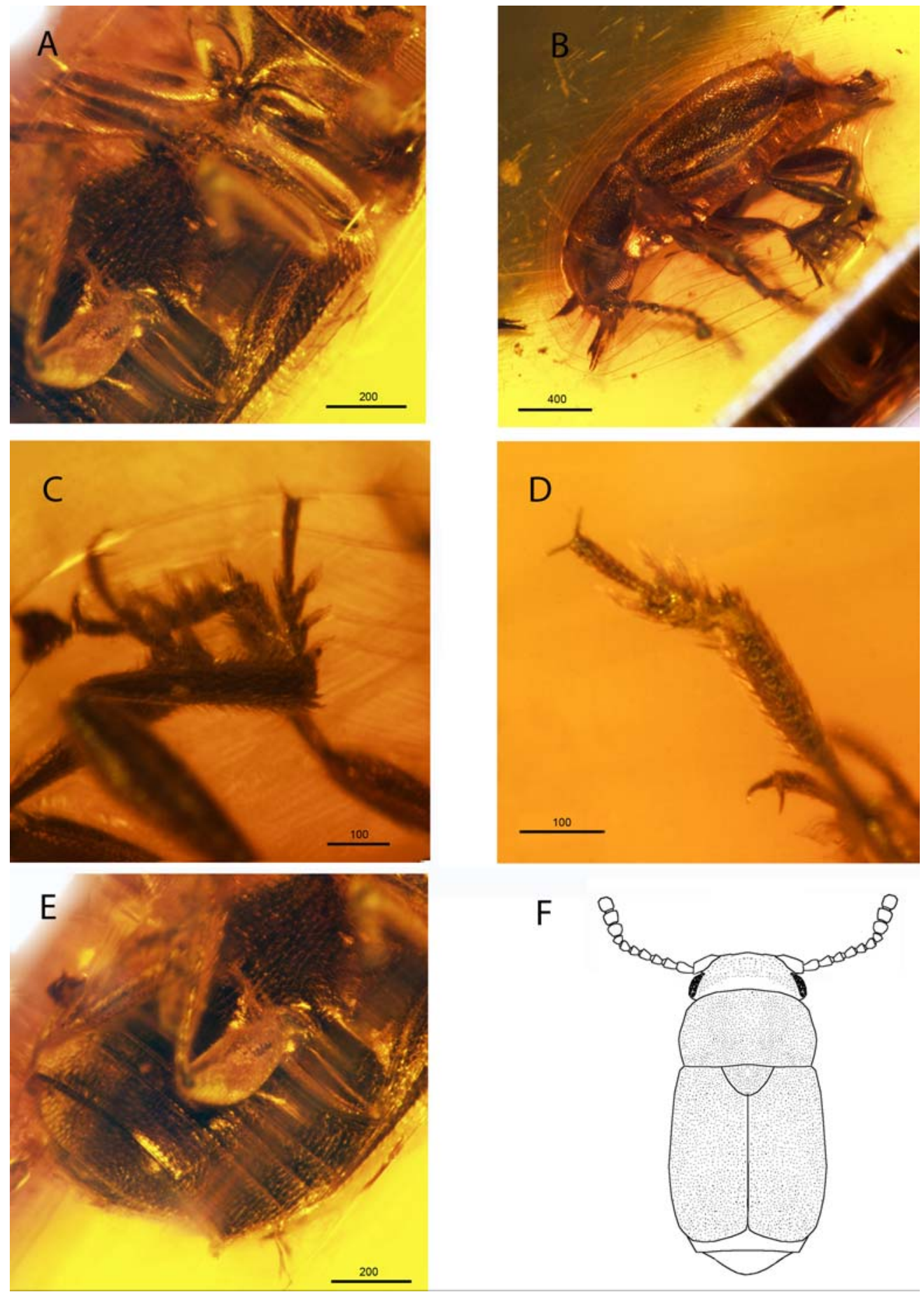

Fig. 2. Heterhelus buzina sp.n. (photo and drawing): A - meso- and metathorax, ventral; B - total view, lateral; C - tibia and tarsus II and III; D - claw; E - abdomen; F — total view, dorsal, line drawings. Рис. 2. Heterhelus buzina sp.n., фото и рисунок: А — средне- и заднегрудь, вентрально; В - общий вид, латерально; C — голени и лапки II и III; D — коготок лапки; Е — брюшко; F — общий вид, дорзально. 
times larger than the greatest length of the sixth abdominal sternite (Fig. 2E). Legs flattened; protibiae rather slender and short, shorter than the greatest width of the head, including the eyes. Tibia with a pair of spurs in the inner apical angle. Tarsi 5-5-5, with three basal tarsomeres subequal in length, strongly lobed. Tarsal claws simple, somewhat bulbous, but without a basal tooth (Fig. 2C, D).

Scutellar shield stout, triangular, apically rounded. Elytra truncated, exposing two complete abdominal tergites (Fig. 2B). Elytral disc diffusely puncturated. Elytra conjointly 1.2 times as long as wide, 2.2 times as long as the pronotum; punctures on disc larger and shallower than those on the pronotum. Abdominal tergite VI partially obscured by elytra. Abdominal tergite VII fully exposed, apex rounded.

ETYMOLOGY. Buzina is the Russian and Ukrainian name for Sambucus.

\section{Discussion}

It differs from almost all fossil species by its slightly shortened elytra; in most species, they leave three abdominal segments completely free. Of the many extinct genera and species, the new species is different in size: Furcalabratum burmanicum $2.6 \mathrm{~mm}$, elytra with rows of punctures, scapus large; Cretaretes minimus very small (1.6 mm), tarsus without lobes, scapus large; Eoceniretes yantaricus $2 \mathrm{~mm}$, scutellum with transversal groove; Lebanoretes andelmani very small $(1.5 \mathrm{~mm})$ and very shortened elytra, leaving the last three abdominal segments completely exposed, scapus large; Electrumeretes birmanicus $1.65 \mathrm{~mm}$, shortened elytra, leaving the last three abdominal segments completely exposed; Polliniretes penalveri $2.9 \mathrm{~mm}$, shortened elytra, leaving the two last abdominal segments and part of the third completely exposed, elytra with rows of punctures; Heterhelus expressus $3.6 \mathrm{~mm}$, much longer.

Heterhelus differs from the similar genus Kateretes in the following characteristics: the points on the pronotum are smaller than the facets of the eye, the posterior angles of the pronotum are not rounded, but angulated. In the middle of the abdominal sternites there are no areas with dense long hairs.

The genus Heterhelus includes seven extant species, zoogeographic characteristics in Hisamatsu (2011); all species are associated with Sambucus L., 1753 (Spornraft, 1967; Audisio, 1993; Jelínek, Cline, 2010).

Differences from the closely related species Heterhelus scutellaris (Heer, 1841): antenna with 3 segmented club (in H.scutellaris the $9^{\text {th }}$ segment is narrower and the club is almost twosegmented); the size of H.scutellaris is 2.2-3.1 $\mathrm{mm}$, whereas the new species is $1.8 \mathrm{~mm}$. The punctures on the head of the new species are less frequent, and the distance between them is greater than the diameter of the puncture. Elytra of H.scutellaris rounded separately, each elytra independently rounded at the apex; in the new species the elytra are obliquely cut from the outside to the inside. The scutellum in the new species is larger and has the shape of an equilateral triangle, while in H.scutellaris it is an isosceles triangle; the new species has a longer scutellum.

Heterhelus scutellaris is related to an ecological type that is oligotrophic, anthophagous and spermatophagous. Perhaps an extinct species similar to it was characterized by similar food preferences. Sibero-European Heterhelus scutellaris and $H$. solani are living in mesophilous forests and shady habitats, at the edges of streams; at the larval stage within ripening fruits of Sambucus (Adoxaceae), especially on S. racemosa L. and S. nigra L., and adults mostly on flowers on their host-plants (Audisio et al., 2000).

The new species is easily distinguished from the Ypresian Heterhelus expressus,: the latter has a larger size (length $3.6 \mathrm{~mm}$ ) and is reddish brown with a round dark spot at the inner apical angle of each elytron.

Extant species of the genus are distributed in the following regions.

Heterhelus (Boreades) solani (Heer, 1841) is distributed in Europe, Eastern Siberia, the Far East of Russia, Mongolia, S. Korea and Japan (Sibero-European by Audisio et al., 2000). Larval development on Sambucus racemosa $\mathrm{L}$ and S. nigra (Audisio et al., 2000). 
Heterhelus (Boreades) abdominalis (Erichson, 1843) is distributed in Canada from New Brunswick to Manitoba, in USA south to Georgia, and west to Texas, Arkansas, Missouri, Nebraska, Kansas, and Iowa (Majka et al., 2008 and references therein). Larval development, probably, on Sambucus canadensis L.

Heterhelus (Heterhelus) morio (Reitter, 1878 ) is distributed in Japan. Larval development on Sambucus racemosa $\mathrm{L}$.

Heterhelus (Heterhelus) satoi Hisamatsu et Lee, 2007 is distributed in Taiwan. Larval development, probably, on Sambucus javanica Blume (syn. Sambucus formosana Nakai).

Heterhelus (Heterhelus) scutellaris (Heer, 1841 ) is distributed in Europe, Eastern Siberia, the Far East of Russia, Mongolia and Japan (Sibero-European by Audisio et al., 2000). Larval development on Sambucus racemosa L. and S. nigra (Audisio et al., 2000).

Heterhelus (Heterhelus) sericans (LeConte, 1869) is distributed in Canada from Newfoundland to British Columbia, in USA south to North Carolina and Tennessee, and west to Kansas and Wisconsin. (Majka et al., 2008 and references therein). Larval development, probably, on Sambucus pubens Michaux, and Sambucus canadensis L.

Heterhelus (Taiwanoheterhelus) nigricans Hisamatsu et Lee, 2007 is distributed in Taiwan. Larval development, probably, on Sambucus javanica Blume.

It should be noted that in Taiwan only one specimen of almost 1900 specimens of Taiwanese Heterhelus was reliably collected below $1800 \mathrm{~m}$. Almost all specimens were collected at an altitude of 1800 to $2600 \mathrm{~m}$ (Hisamatsu, Lee, 2007), i.e. they originate from subtropical cloud mountain forests.

Thus, all extant species of Heterhelus develop on Sambucus; subfossil Heterhelus records were used as a proxy for Sambucus (Young, 1984).

Heterhelus is divided into subgenera mainly according to the structure of the antennae club and terminal segment of the labial palpus (Hisamatsu, Lee, 2007). The labrum of subgenus Heterhelus is deeply notched and has antenna with an indistinct 3-segmented club. Subgenera Boreades and Taiwanoheterhelus have a shallow notched labrum and antenna with a distinct 3-segmented club. Subgenus Boreades differs from subgenus Taiwanoheterhelus by its terminal segment of the labial palpus; not slender Boreades, slender - Taiwanoheterhelus. The club of the new species is indistinct. The new species belongs to the subgenus Heterhelus.

Before the Oligocene Sambucus was known in Europe from the thermophile biotas of Reading Beds and Cliff End Beds (corresponding to the Paleocene/Eocene boundary and the Bartonian, England), and Eckfeld (Lutetian, Germany). Priabonian records belong to equable biotas of Florissant (USA, Colorado) (Allen et al., 2020) and Novosibirsk Region (Western Siberia). From the whole of Eastern Europe (including Russoscandia) Paleogene records of Sambucus are not known.

Heterhelus was not found in the huge Klebs collection, although the genus was well known to Edmund Reitter, who determined the beetles (Klebs, 1910); 'Sambucus' species from Baltic amber have too many petals to belong to Sambucus (Cockerell, 1910), so this record is the first indication of Sambucus presence in Priabonian amber forests. Based on the modern and Eocene distribution of Sambucus and Heterhelus, it can be assumed that Heterhelus adapted to feeding on Sambucus in regions with an equable climate, in which both genera are found in the late Eocene, which prevents Heterhelus from spreading further towards south, to regions with hotter summers, included in the modern range of Sambucus.

As only Sambucus endocarps provide highly reliable generic diagnostic characteristics (Huang et al., 2012), Heterhelus fossil records (except the questionable Oise one) can be used as a proxy for Sambucus, e.g. H. buzina for the oldest Sambucus record for Eastern Europe.

\section{Compliance with ethical standards}

CONFLICTS OF INTEREST: The authors declare that they have no conflicts of interest.

Acknowledgements. The study of the second author (GL) was supported by State Pro- 
gram "Taxonomic and Biochorologic Analysis of the Animal Kingdom as the Basis for the Study and Preservation of the Structure of Biodiversity", MSU Zoological Museum. We are grateful to Dr. Toshiharu Mita (Kyushu University, Fukuoka, Japan) for help with Japanese papers.

\section{References}

Allen S.E., Lowe A.J., Peppe D.J., Meyer H.W. 2020. Paleoclimate and paleoecology of the latest Eocene Florissant flora (Central Colorado, USA) // Palaeogeography, Palaeoclimatology, Palaeoecology. Vol.551. Art.109678.

Audisio P. 1993. Coleoptera Nitidulidae, Kateretidae // Fauna d'Italia. Vol.32. Bologna: Calderini ed. 971 pp.

Audisio P., Jelinek J., Mariotti A., De Biase A. 2000. The Coleoptera Nitidulidae and Kateretidae from Anatolian, Caucasian and Middle East regions // Biogeographia - The Journal of Integrative Biogeography. Vol.21. No.1. P.241-354.

Bellés X., Perkovsky E.E. 2016. New data on the genus Sucinoptinus (Coleoptera, Ptinidae) from Rovno amber // Vestnik zoologii. Vol.50. No.1. P.17-22.

Bogri A., Solodovnikov A., Żyła D. 2018. Baltic amber impact on historical biogeography and palaeoclimate research: oriental rove beetle Dysanabatium found in the Eocene of Europe (Coleoptera, Staphylinidae, Paederinae) // Papers in Palaeontology. Vol.4. No.3. P.433-452.

Bukejs A., Biondi M., Alekseev V.I. 2016. New records and species of Crepidodera Chevrolat (Coleoptera: Chrysomelidae) in Eocene European amber, with a brief review of described fossil beetles from Bitterfeld amber // Zootaxa. Vol.4193. No.2. P.390-400.

Bukejs A., Háva J., Alekseev V.I. 2020. A new fossil species of Attagenus Latreille (Coleoptera: Dermestidae) in Rovno and Baltic ambers, with a brief review of known fossil beetles from the Rovno amber Lagerstätte // Fossil Record. Vol.23. P.95-104.

Bukejs A., Legalov A.A. 2019a. First record of the tribe Naupactini (Coleoptera: Curculionidae) in Rovno amber // Fossil Record. Vol.22. P.25-30.

Bukejs A., Legalov A.A. 2019b. The first record of Rhynchitidae (Coleoptera) from Rovno amber // Entomologica Fennica. Vol.30. No.4. P.168-172.

Bukejs A., Legalov A.A. 2020. The first record of Brentidae (Coleoptera) in Eocene Rovno amber with description of a new fossil species of Toxorhynchus Scudder, 1893 // Fossil Record. Vol.23. P.169-177.

Cockerell T.D.A. 1910. Notes on the genus Sambucus // Torreya. Vol.10. No.6. P.125-128.

Hisamatsu S. 2011. A review of the Japanese Kateretidae fauna (Coleoptera: Cucujoidea) // Acta Entomologica Musei Nationalis Pragae. Vol.51. No.2. P.551-585.

Hisamatsu S.-T., Lee C.-F. 2007. A revision of the genus Heterhelus Jacquelin du Val of Taiwan (Coleoptera,
Kateretidae) // Japanese Journal of Systematic Entomology. Vol.13. No.2. P.377-385.

Huang Y., Jacques F.M.B., Liu Y.-Sh., Su T., Xing Y., Xiao X., Zhou Z. 2012. New fossil endocarps of Sambucus (Adoxaceae) from the upper Pliocene in SW China // Review of Palaeobotany and Palynology. Vol.171. P.152-163.

Jałoszyński P., Perkovsky E.E. 2016. Diversity of Scydmaeninae (Coleoptera: Staphylinidae) in Upper Eocene Rovno amber // Zootaxa. Vol.4157. No.1. P.1-85.

Jałoszyński P., Perkovsky E.E. 2019. The Mastigitae genus $\uparrow$ Baltostigus in Upper Eocene Rovno amber (Coleoptera: Staphylinidae: Scydmaeninae) // Zootaxa. Vol.4661. No.3. P.594-600.

Jelínek J., Cline A.R. 2010. Chapter 10.25. Kateretidae Erichson in Agassiz, 1846. // R.A.B. Leschen, R.G. Beutel, J.F. Lawrence (eds.): Handbook of Zoology, Arthropoda: Insecta, Coleoptera, Beetles Morphology and Systematics. Berlin, New York: De Gruyter. P.386390.

Kazantsev S.V., Perkovsky E.E. 2020.The first Cacomorphocerus species (Coleoptera, Cantharidae) from Rovno amber: a second species of the genus with 11segmented antennae // Zootaxa. Vol.4751. P.395400.

Kirejtshuk A.G., Azar D. 2008. New taxa of beetles (Insects, Coleoptera) from Lebanese amber with evolutionary and systematic comments // Alavesia. Vol.2. P.15-46.

Kirejtshuk A.G., Nel A. 2008. New beetles of the suborder Polyphaga from the Lowermost Eocene French amber (Insecta: Coleoptera) // Annales de la Société entomologique de France. Vol.44. No.4. P.419-442.

Klebs R. 1910. Über Bersteineinschlüsse im allgemeinen und die Coleopteren meiner Bernsteinsammlung // Schriften der physikalisch-ökonomischen Gesellschaft zu Königsberg i Pr. Bd.5. S.217-242.

Kupryjanowicz J., Lyubarsky G.Yu., Perkovsky E.E. 2019. [New species of family Smicripidae (Coleoptera: $\mathrm{Cu}-$ cujoidea) from Rovno amber] // Paleontologicheskii Zhurnal. No.2. P.72-75 [in Russian; English translation: Paleontological Journal. Vol.53. No.2. P.5559].

Kypke J.L., Solodovnikov A. 2020. Every cloud has a silver lining: X-ray micro-CT reveals Orsunius rove beetle in Rovno amber from a specimen inaccessible to light microscopy // Historical Biology. Vol.32. No.7. P.940-950.

Legalov A.A., Nazarenko V.Yu., Perkovsky E.E. 2018. A new genus of fungus weevils (Coleoptera: Anthribidae) in Rovno amber // Fossil Record. Vol.21. P.207-212.

Legalov A.A., Nazarenko V.Yu., Perkovsky E.E. 2019. amber // Paleontological Journal. Vol.53. No.10. P.1045-1059.

Legalov A.A., Nazarenko V.Yu., Perkovsky E.E. 2021. A new species of the genus Glaesotropis Gratshev et Zherikhin, 1995 (Coleoptera, Anthribidae) from Rovno amber // Fossil Record. Vol.24. P.1-7. 
Lyubarsky G.Yu., Perkovsky E.E. 2020. First Rovno amber species of the genus Telmatophilus (Coleoptera: Clavicornia:Cryptophagidae) from Veselukha floodplain // Invert. Zool. Vol.17. No.1. P.25-35.

Majka C.G., Webster R., Cline A.R. 2008. New records of Nitidulidae and Kateretidae (Coleoptera) from New Brunswick, Canada // C.G. Majka, J. Klimaszewski (eds.). Biodiversity, biosystematics, and ecology of Canadian Coleoptera. ZooKeys. Vol.2. P.337-356.

Nadein K.S., Perkovsky E.E., Moseyko A.G. 2016. New Late Eocene Chrysomelidae (Insecta: Coleoptera) from Baltic, Rovno and Danish ambers // Papers in Palaeontology. Vol.2. No.1. P.117-137.

Nazarenko V.Yu., Perkovsky E.E. 2016. A new species of derelomine weevils (Coleoptera, Curculionidae, Curculioninae: Acalyptini) from the Rovno amber // $\mathrm{Pa}$ leontological Journal. Vol.50. No.9. P.991-996.

Peris D., Jelínek J. 2019. Atypical short elytra in Cretaceous short-winged flower beetles (Coleoptera: Kateretidae) // Palaeoentomology. Vol.2. No.5. P.505-514.

Peris D., Jelínek J. 2020. Syninclusions of two new species of short-winged flower beetle (Coleoptera: Kateretidae) in mid-Cretaceous Kachin amber (Myanmar) // Cretaceous Research. Vol.106. Art.104264.

Peris D., Labandeira C.C., Barron E., Delclos X., Rust J., Wang B. 2020. Generalist pollen-feeding beetles during the mid-Cretaceous // iScience. Art.100913.

Perkovsky E.E. 2016. [A new species of Micromalthidae (Coleoptera) from the Rovno amber: 1. Adult morphology] // Paleontologicheskii Zhurnal. No.3. P.8387 [in Russian; English translation: Paleontological Journal. Vol.50. No.3. P.293-296].

Petrov A.V., Perkovsky E.E. 2018. [A new genus and new species of Scolytinae from Rovno amber (Insecta: Coleoptera: Scolytidae)] // Paleontologicheskii Zhur- nal. No.2. P.55-57 [in Russian; English translation: Paleontological Journal. Vol.50. No.2. P.164-167].

Poinar G.O., Brown A.E. 2018. Furcalabratum burmanicum gen. et sp. nov., a short-winged flower beetle (Coleoptera: Kateretidae) in mid-Cretaceous Myanmar amber // Cretaceous Research. Vol.84. P.240-244.

Radchenko A.G., Perkovsky E.E. 2020. [New records of the fossil ant genus Prionomyrmex Mayr (Hymenoptera, Formicidae, Myrmeciinae) from late Eocene European ambers] // Paleontologicheskii Zhurnal. No.6. P.60-67 [in Russian; English translation: Paleontological Journal. Vol.54. No.6. P.617-626].

Simutnik S.A., Perkovsky E.E., Vasilenko D.V. 2020. First record of Leptoomus janzeni Gibson (Hymenoptera, Chalcidoidea) from Rovno amber // Journal of Hymenoptera Research. Vol.80. P.137-145.

Sokolov A.V., Perkovsky E.E. 2020. The first Eocene species of Bacanius (Coleoptera: Histeridae: Dendrophilinae) from Rovno amber // Russian Entomological Journal. Vol.29. No.2. P.157-160.

Spornraft K. 1967. 50 - Familie Nitidulidae // H. Freude, K.W. Harde, G.A. Lohse (Hrsg.). Die Käfer Mitteleuropas. Vol.7. Krefeld: Goecke \& Evers Verlag. S.20-77.

Tshernyshev S.E. 2016. New taxa of soft-winged flower beetles (Coleoptera, Malachiidae) in Baltic and Rovno amber// Paleontological Journal. Vol.50. No.9. P.953962.

Wickham H.F. 1912. A report on some recent collections of fossil Coleoptera from the Miocene shales of Florissant // Bulletin from the Laboratories of Natural History of the State University of Iowa. Vol.6. P.3-38.

Young R.Ch. 1984. A thesis presented for the degree of Doctor of Philosophy at the University of London. Department of Geography. Bedford College. N.W.1. Ann Arbor. 515 p.

Responsible editor K.G. Mikhailov 